\title{
PERNIKAHAN LINTAS AGAMA DALAM PANDANGAN KAUM FUNDAMENTALIS
}

\author{
Tajul Arifin \\ (Program Pascasarjana UIN Sunan Kalijaga Yogyakarta, jln. Marsda di Sucipto, \\ Yogyakarta, email:aatajul@yahoo.co.id)
}

\begin{abstract}
Abstrak
Ketentuan hukum perkawinan antaragama telah dinyatakan secara tegas dalam al-Qur'an. Paling tidak ada tiga mainstream pemikiran dalam masalah ini. Pertama mengharamkan secara mutlak perkawinan beda agama. Kedua, membolehkan dengan syarat tertentu. Ketiga membolehkan tanpa syarat. Ketiga pendapat ini merupakan hasil interpretasi terhadap QS. al-Mâ`idah (5): 5, QS. al-Baqarah (2): 22, dan QS. al-Mumtahanah (60): 10. Karenanya, kajian ini diarahkan pada bagaimana pandangan ulamâ' fundamentalis terhadap pernikahan lintas agama. Dalam kajian ini, penulis menggunakan metode kualitatif, yaitu dengan cara pengamatan, wawancara secara bebas terhadap sumber-sumber yang telah ditentukan, dan pemanfaatan atau penelaahan dokumen. Lokasi yang dipilih adalah Solo, karena kota ini dipandang sebagai sarang kaum fundamentalis. Sedangkan mengenai respon yang diberikan beberapa ulamâ' fundamentalis di solo terhadap persoalan ini, hampir semua jawaban yang penulis dapatkan sangatlah normatif. Karena bagi mereka persoalan produk hukum agama haruslah difahami secara fundamental, karena keputusan Tuhan yang ada dalam al-Qur'an merupakan keputusan final dalam persoalan apa pun, kecuali jika belum secara jelas tertera.
\end{abstract}

\section{Abstract}

The rule of inter-religious marriage law have been stated clearly in the Qur'an. There are at least three mainstreams of idea in this problem. First, forbid the marriage of different religion expressly. Second, allow the marriage of different religion by certain requirements. Third, allow the marriage of different religion without any requirements. These three opinions are the result of interpretations of $Q S$. al-Mâ'idah (5): 5, QS. al-Baqarah (2): 22, and QS. al- 
Tajul Arifin

Mumtahanah (60):10. Because of them, this study is oriented to how the view of fundamental ulamâ' to the interreligious marriage. In this study, the writer used qualitative method; by using observation, interview freely with the informant chosen, and also documentation. The location chosen was Solo because this town viewed as a place of fundamentalis. The respond given by fundamental ulamá in Solo about this case that almost the answers are normative since for them, the product of the religious law should be understood fundamentally, for the decision of God written in al-Qur'an is final decision on any matters except if it is not clearly stated.

\section{Kata-kata kunci}

pernikahan, lintas agama, Ahl al-Kitâb, fundamentalis

\section{Pendahuluan}

Menurut fitrahnya, manusia dilengkapi Tuhan dengan kecenderungan seks (libido seksualitas). Oleh karena itu, Tuhan menyediakan wadah yang legal untuk terselenggaranya penyaluran tersebut yang sesuai dengan derajat kemanusiaan, yakni perkawinan. Akan tetapi, perkawinan tidaklah semata-mata dimaksudkan untuk menunaikan hasrat biologis tersebut. Terdapat tujuan lainnya dari sebuah perkawinan, yaitu untuk mencapai kehidupan sakînah, mawadah dan rahmah, regenerasi, menjaga kehormatan, dan beribadah, ${ }^{1}$ serta menjalin hubungan kekeluargaan.

Hukum perkawinan Islam dibangun untuk menciptakan kemaslahatan bagi seluruh manusia dan bagi pihak-pihak yang bersangkutan dengan pernikahan tersebut. Secara umum, kemaslahatan perkawinan adalah segala sesuatu yang merupakan kebaikan atau yang menyebabkan timbulnya kebaikan dan bukan merupakan sebuah kemudaratan atau sesuatu yang menolak

\footnotetext{
1 Khoruddin Nasution, Islam Tentang Relasi Suami dan Istri (Hukum Perkawinan 1) Dilengkapi Perbandingan UU Negara Muslim (Yogyakarta: Academia dan Tazzafa, 2004), hlm. 35-50. Sebagian komentar ada yang berpendapat bahwa memperoleh anak bukanlah merupakan tujuan perkawinan, tetapi lebih pada sesuatu yang boleh ada dan boleh juga tidak. Artinya apabila tidak tercapai, maka tidak merusak perkawinan.
} 
munculnya berbagai kemudaratan di dalam kehidupan perkawinan bagi pihak yang bersangkutan dan bagi masyarakat di sekitarnya. ${ }^{2}$

Kemaslahatan perkawinan juga berarti segala sesuatu yang digunakan untuk meraih maqâshid al-syarî’ah dari perkawinan, baik yang bersifat ashliyyah atau thabî'ah, dan dlarûriyyah, mukmilah dlarûriyyah, hâjizyyah maupun mukmilah hâjjiyyah. Kemaslahatan perkawinan yang termasuk ke dalam ashliyyah adalah meneruskan keturunan yang merupakan penjagaan langsung terhadap salah satu al-ushûl al-khamsah ${ }^{3}$ yang berupa al-nasl. Sedangkan kemaslahatan perkawinan yang bersifat thabîah adalah mencari ketenangan (sakînah), membagi cinta dan kasih sayang (mawaddah wa al-rahmah), menyalurkan kebutuhan biologis secara benar dan sebagainya yang merupakan penjagaan tidak langsung terhadap aspek al-nasl.4

Kemaslahatan perkawinan yang berupa meneruskan keturunan tersebut juga berarti mashlahah dlarûriyyah. Kemaslahatan perkawinan yang berupa penyaluran biologis secara benar (menolak zina) merupakan mukmilah al-dlarûriyyah. Sedangkan kemaslahatan yang berupa kelanggengan ikatan perkawinan, keharmonisan rumah tangga, saling berbagi kasih sayang, ketenangan dan cinta adalah maslahah hajiyyah. ${ }^{5}$

Pertanyaannya kemudian untuk mencari kemaslahatan dalam ikatan perkawinan apakah juga harus terbatas pada keyakinan atau agama yang sama? Inilah yang menjadi topik utama dalam kajian ini,

\footnotetext{
2 Pemaknaan mashlahah dalam perkawinan tersebut merupakan pemahaman dari arti mashlahah itu sendiri, mashlahah adalah setiap yang mengandung kemanfaatan baik dengan cara mencari kegunaan dan kenikmatan maupun dengan cara menolak bahaya dan rasa sakit. Bias juga mashlahah berarti mengambil manfaat dan menolak kemudaratan. Lihat Nasrun Haroen, Ushul Fikih I (Bandung: Logos, 1997), hlm. 114; Abd al-Wahab Khallâf, Ushûl al Figh (Kairo: Dâr al-Qalam, 1978), hlm. 198.

${ }^{3}$ Maksudnya adalah lima hal mendasar yang menjadi pokok kebutuhan kehidupan manusia, dan wajib adanya untuk menegakkan kemaslahatan bagi manusia. Lima hal yang harus dijaga yaitu: agama, jiwa, akal, harta dan kehormatan. Lihat Yudian Wahyudi, Ushul fikih versus Hermeneutika; Membaca Islam dari Kanada dan Amerika, cet. I (Yogyakarta: Nawesea Press, 2006), hlm. 45; Ahmad al-Mursi Husayn Jauhar, Maqâashid al-syarî'ah, cet. I (Jakarta: amzah, 2009), hlm. xi-xv.

4 Yûsuf Hâmid 'Âlim, al-Maqâshid al-'Âmmah li al-Syarî'ah al-Islâmiyyah (USA: Internasional Graphics Printing Service, 1991), hlm. 102.

${ }^{5}$ Wahbah al-Zuhaylî, Ushûl al-Figh al-Islâmi, juz II (Damaskus: Dâr al-Fikr, 1986), hlm. 772 dan 1025.
} 
Tajul Arifin

yang akan dijawab secara luas baik dalam tela'ah teks maupun pendapat para cendekiawan di lokasi penelitian.

\section{Pernikahan Beda Agama dalam Perspektif Figh dan Hukum Positif di Indonesia}

Terdapat perbedaan di kalangan ulamâ’ tentang perkawinan beda agama. Sebagian ulamâ` membolehkan tetapi tidak sedikit pula yang mengharamkan. Ulamâ' juga berbeda pendapat terhadap cakupan Ahl al-Kitâb, di mana laki-laki Muslim diperbolehkan mengawini golongan mereka. ${ }^{6}$

Golongan ulamâ' yang mengharamkan perkawinan laki-laki Muslim dan perempuan Ahl al-Kitâb, disebabkan oleh pandangan mereka bahwa perempuan Ahl al-Kitâb mempunyai kedudukan yang sama dengan perempuan musyrik. Padahal baik laki-laki maupun perempuan Muslim dilarang menikah dengan orang-orang musyrik. ${ }^{7}$ menurut golongan ini, Ahl al-Kitâb mempunyai kedudukan yang sama dengan orang musyrik, karena orang-orang Ahl al-Kitâb juga mempertuhankan orang alim mereka, rahib-rahib dan mengakui bahwa Uzayr atau Isa sebagai putera Allah. ${ }^{8}$

Ibnu umar termasuk golongan yang mendukung pendapat ini. Menurutnya, Allah mengharamkan perempuan musyrik bagi laki-laki Muslim. "aku tidak tahu syirik manakah yang lebih besar dari seorang perempuan yang mengatakan bahwa Tuhannya adalah Isa". ${ }^{9}$

Larangan ini disebabkan oleh terjadinya dinamika sosial, kebutuhan komunitas Muslim untuk memelihara kohesi sosial dan integritas ummatnya. ${ }^{10}$ Larangan oleh suatu ketentuan yang oleh nash diperbolehkan dengan pertimbangan mafsadah lebih besar dari kalangan mashlahah dalam kajian Ushûl al-Fiqh disebut sadd al-dzarî'ah (tindakan preventif). Perubahan hukum dikarenakan perubahan keadaan dan dinamika sosial itu bisa jadi terjadi sesuai dengan kaidah

\footnotetext{
6 Al-Qur`an, al-Mâ'idah (5): 5

7 Al-Qur`an, al-Baqarah (2): 221.

8 Al-Qur`an, al-Mâ`idah (5): 72-73; al-Qur`an, al-Tawbah (9): 30-31.

${ }^{9}$ Ibnu Hazm, al-Muhalla bi al-Asrâr, juz XI (Beirut: Dâr al-Kutub al-Ilmiyâh, 1988), 13.

10 Majelis Tarjih dan Pengembangan Pemikiran Islam PP Muhammadiyah, Tafsir Tematik al-Qur an (Yogyakarta: tnp., 2000), hlm. 29.
} 
hukum Islam (qawâ'id al-fighiyyah), "tidak diingkari perubahan hukum karena perubahan zaman dan tempat". ${ }^{11}$

Wahbah al-Zuhaylî menambahkan, di samping alasan di atas, dilarangnya perkawinan beda agama, karena mereka orang-orang non-Muslim, mengajak ke neraka. ${ }^{12}$ Kepercayaan-kepercayaan musyrik dikhawatirkan akan mempengaruhi laki-laki dan perempuan Muslim dengan menimbulkan berbagai macam keraguan dan kesesatan. Dengan demikian, kekhawatiran akan adanya pengaruh negatif terhadap keimanan seseorang merupakan sebab dilarangnya perkawinan beda agama di Indonesia.

Adapun jumhûr ulamâ' berpendapat bahwa laki-laki Muslim diperbolehkan menikah dengan perempuan Ahl al-Kitâb.13 Menurut mereka lafazh musyrikah tidak mencakup Ahl al-Kitâb. Hal ini didasarkan pada firman Allah dalam surah al-Baqarah (2): 105 dan alBayyinah (98): 1 dan 6.

Pernikahan beda agama sebagai fakta sosial bukanlah isu baru, namun secara historis pernikahan beda agama ini telah terjadi di kalangan tokoh-tokoh Islam sejak zaman nabi Muhammad saw, kemudian masa sahabat, tâbi'în, hingga masa-masa berikutnya dan berlanjut hingga sekarang. ${ }^{14}$ Lebih-lebih dalam konteks masyarakat

11 Ali Ahmad al-Nadawi, al-Qawấ'id al-Fighiyyah (Damaskus: Dâr al-Qalam, 1991), hlm. 123.

12 Wahbah Zuhaylî, al-Figh al-Islâm wa Adillatuh, juz VII (Beirut: Dâr al-Fikr, 1989), hlm. 152.

13 Al-Jazirî, Kitâb al-Fiqh 'alâ Madzâhib al-Arba'ah (Beirut: Dâr al-Fikr, 1996), hlm. 68-70.

14 Rasulullah saw, menikahi Mariah al-Qibthiyyah, seorang penganut Kristen Koptik yang dihadiahkan oleh Gubernur Mesir, Maukaukis, setelah perang Khaibar. Rasulullah saw, juga mengawini Shâfiyah binti Huyai bin Akhthab, seorang Yahudi dari bani Nazhîr. "Utsmân bin 'Affân menikah dengan perempuan Kristen bernama Naylah binti al-Farâfishah al-kalâbiyyah yang selanjutnya memeluk islam, lalu Hudzayfah bin al-Yamani menikahi perempuan Yahudi dari Madâ'in, kemudian Thalhah Ubaydillâh menikah dengan perempuan Kristen, dan masih banyak lagi sahabat lain yang melakukan praktik pernikahan beda agama ini, terutama pada waktu mereka melakukan ekspansi Islam (fat $\underline{h}$ ) ke berbagai wilayah di luar Madinah. Lihat Wahbah al-Zuhaylî, al-Figh al-Islâm wa Adillatuhu, juz VII (Beirut: Dâr al-Fikr, 1984), hlm. 153-155. Lihat juga Sayyid Sâbiq, Figh al-Sunnah, juz II (Beirut: Dâr al-Fikr, 1983), hlm. 90-91. Tokoh penting lain setelah sahabat yang melakukan praktik pernikahan beda agama antara lain, Husayn bin Ali yang sempat mengawini putri Kisra Persia yang beragama Majusi, dan Sultan Akbar dari dinasti Moghul yang memperistri putri bangsawan Rajput yang beragama Hindu. Ada indikasi kuat bahwa pernikahan beda agama ini dijadikan sebagai dakwah untuk menarik orang 
Tajul Arifin

plural dalam etnis, budaya, dan agama seperti di Indonesia, perkawinan beda agama menjadi sebuah fakta yang wajar dan sangat mungkin terjadi.

Dalam konteks Indonesia, aturan mengenai pernikahan beda agama sudah ada sejak zaman prakemerdekaan. ${ }^{15}$ Pascakemerdekaan aturan mengenai pernikahan beda agama dapat dijumpai pada UU perkawinan No. 1 tahun 1974, meskipun tidak secara expresif verbis UU ini juga melarang terjadinya kawin beda agama. Aturan yang lebih rigid, dapat ditemukan dalam Inpres No. 1 tahun 1991 mengenai Kompilasi Hukum Islam (KHI). ${ }^{16}$ Sementara MUI menegaskan larangan pernikahan beda agama di Indonesia melalui fatwa tahun 1980 dan tahun 2005 sampai pada level pengharaman.

\section{Metode Kajian}

Kajian ini berusaha memahami, dengan menggunakan pemahaman dan interpretasi tentang respon ulamâ" di Solo terhadap pernikahan lintas agama. Dengan karakter seperti itu, penelitian ini adalah penelitian kualitatif.

Data yang dibutuhkan dalam penelitian ini dikumpulkan dengan menggunakan "metode kualitatif", yaitu pengamatan (observasi), wawancara (interview), dan pemanfaatan atau penelaahan dokumen. ${ }^{17}$ Metode ini meletakkan manusia, yakni peneliti sendiri atau orang lain yang membantunya, sebagai instrumen utama sehingga tindakan penyesuaian yang perlu segera diambil dalam

non Islam ke dalam Islam. Dan sejarah membuktikan bahwa tersebarnya Islam di pelbagai penjuru dunia, masa lalu dan sekarang, justru banyak lewat pintu perkawinan tersebut.

${ }^{15}$ Lihat Statblaab, 1898, no. 158. Tentang Peraturan Perkawinan Campuran.

${ }^{16}$ Lihat pasal 40 dan 44 Kompilasi Hukum Islam. KHI mengkategorikan perkawinan antar pemeluk agama ke dalam bab larangan perkawinan. Secara lengkap bunyi pasal tersebut adalah, pasal 40 poin C, Dilarang melangsungkan perkawinan antara seorang pria dengan Seorang perempuan yang tidak beragama Islam, dan pasal 44, seorang perempuan Islam dilarang melangsungkan perkawinan dengan seorang yang tidak beragama Islam. Team Media, Amandemen UU Peradilan Agama (UU RI No. 3 Tahun 2006), Undang-undang Peradilan Agama (Nomor 7 Tahun 1989) dan Kompilasi Hukum Islam (ttp.: Media Centre, t.t.), hlm. 130-131.

17 Lexy J Moleong , Metodologi Penelitian Kualitatif (Bandung: PT. Remaja Rosdakarya, 2005), hlm. 5 dan 9. 
kaitannya dengan kenyataan-kenyataan di lapangan menjadi sangat mungkin dilakukan.

Selanjutnya, karena penelitian kualitatif ini berlatar alamiyah dan menekankan aspek subyektif dari perilaku orang sehingga peneliti akan berhadapan dengan kenyataan-kenyataan jamak di lapangan, maka diperlukan kerja pengumpulan data yang cermat dan mendalam. Untuk itu kerja pengamatan dilakukan secara berperan serta (participatory observation), kerja wawancara dilakukan secara "mendalam" (indepth interview), dan penelaahan dokumen dilakukan dengan secermat mungkin dan sejauh bisa diupayakan dari data asli.

Dalam penelitian ini, secara umum data dapat diklasifikasikan menjadi dua jenis, yaitu jenis data primer dan jenis data skunder. ${ }^{18}$ Data primer yaitu data yang diperoleh dari secara langsung dikumpulkan oleh peneliti dari sumber pertamanya, 19 dan juga data dari hasil wawancara langsung dengan pihak terkait menggunakan metode pertanyaan (quesioner) kepada ulamâ' di Solo mengenai respon mereka terhadap pernikahan beda agama. Sedangkan data sekunder adalah data yang diambil untuk dilaporkan dan dikumpulkan dari orang luar yang berkaitan dengan penelitian ini, baik secara lisan maupun dari data hasil kepustakaan.

Sumber data dalam penelitian ini adalah lembaga-lembaga organisasi masyarakat (Ormas) Islam di solo yang sering kali mengadakan pengajian mingguan dan sangat berpengaruh terhadap ideologi keislaman masyarakat Solo yang terkenal fundamental. Di antaranya adalah Majlis Tafsir Al-Qur'an (MTA), Jamaah Anshor atTauhid (JAT), Majelis Mujahidin Indonesia (MMI) dan Hidayatullah.

Untuk mengartikulasikan pemahaman, data yang dihasilkan lewat pengamatan, wawancara, dan kajian dokumen dianalisis secara induktif. Sebab, sebagaimana kata Moleong, analisis induktif lebih dapat menemukan kenyataan jamak seperti yang terdapat dalam data. Juga lebih dapat membuat hubungan peneliti-informan eksplisit, dapat dikenal, dan akuntabel; lebih dapat menguraikan latar secara penuh dan dapat membuat keputusan-keputusan tentang dapat atau tidaknya dilakukan pengalihan pada latar lainnya; lebih

18 Winarno Surahman. Metodologi Penelitian (Jakarta: Rajawali, 1989), hlm. 71.

19 Sumardi Subrata, Metodologi Penelitian (Jakarta: PT. Raja Grafindo Persada, 1983), hlm. 84-85. 
Tajul Arifin

dapat menemukan pengaruh bersama yang mempertajam hubunganhubungan; dapat memperhitungkan nilai-nilai secara eksplisit sebagai bagian dari struktur analitik. ${ }^{20}$

\section{Pendapat Ulamâ` Fundamentalis tentang Pernikahan Lintas Agama}

Pembicaraan al-Qur`an tentang perkawinan beda agama dapat ditemukan dalam tiga tempat: Pertama, QS. al-Baqarah (2): 221 yang berbicara tentang ketidakbolehan laki-laki Muslim menikah dengan perempuan musyrik dan ketidakbolehan perempuan Muslim dinikahi oleh laki-laki musyrik. Kedua, QS, al-Mumtahanah (60): 10 yang menegaskan ketidakbolehan perempuan Muslim bagi pria kafir dan sebaliknya. Ketiga, QS al-Mâ`idah (5): 5 yang membolehkan laki-laki Muslim menikahi perempuan Ahl al-Kitâb.

Dari tiga ayat yang sama-sama dijadikan sebagai rujukan dalam merumuskan hukum perkawinan beda agama, ternyata ulamâ` memiliki pendapat yang berbeda-beda.

Islam melarang perkawinan perempuan Muslim dengan lakilaki non Muslim, baik laki-laki Ahl al-Kitâb, musyrik atau atheis. Dengan pertimbangan keselamatan agama, perempuan yang beragama Islam jangan sampai agamanya ditinggal karena pengaruh suaminya. ${ }^{21}$

Tidak halal bagi perempuan Muslim kawin dengan laki-laki non Muslim, baik pengikut faham komunis, Hindu, atau dari Ahl alKitâb. Sebab laki-laki punya hak tanggung jawab mengurusi isterinya, dan isteri harus taat kepada suaminya. Maka tidaklah benar seorang kafir atau musyrik menguasai seorang perempuan yang mengucapkan lâ ilâha illallâh Muhammadur Rasûlullâh. Allah berfirman dalam QS al-Nisâ' (4): 141, bahwa Allah benar-benar tidak akan memberi izin kepada orang-orang kafir menguasai orang-orang beriman. ${ }^{22}$ Ayat ini secara eksplisit memberikan wasiat terhadap perempuan Muslim untuk tidak menikahi laki-laki non Muslim hingga beriman.

20 Meleong, Metodologi, hlm. 10.

21 Ahmad Azhar Basyir, Hukum Perkawinan Islam, hlm. 16.

22 Ibrahim Muhammad al-Jamal, Fiqih Wanita Islam (Jakarta: Pustaka Panjimas, 1991), hlm. 26-27. 
Umar ibn al-Khaththâb ra. menyatakan bahwa tidak halal bagi laki-laki non Muslim menikahi perempuan Muslim selama laki-laki tersebut tetap belum masuk Islam. Sikap Umar ibn al-Khaththâb yang tegas itu didasarkan pada al-Qur`an surat al-Mumtahanah (60) ayat 10.

Ulamâ` berpendapat bahwa al-Qur`an melarang perempuan Muslim menikah dengan laki-laki non Muslim, baik dari kalangan musyrik maupun Ahl al-Kitâb, bahkan Ibn Hazm menyatakan haram secara mutlak.23 Jadi, perempuan Muslim hanya diperbolehkan menikah dengan laki-laki Muslim. Pendapat ini tidak jauh berbeda dengan apa yang disampaikan oleh Ustadz Medi, wakil pimpinan Majlis Tafsir Al-Qur’an di Solo. Beliau menyatakan bahwa fundamental adalah keniscayaan dalam masalah hukum Islam, tekstual dalam masalah agama merupakan langkah yang harus selalu ditempuh untuk menelurkan hasil dari ijtihâd dalam masalah apa pun yang berkaitan dengan agama. Larangan pernikahan ini didasarkan pada al-Qur'an, al-Sunnah, dan ijmâ'. Menurutnya, perempuan Muslim haram hukumnya untuk menikah atau dinikahkan dengan laki-laki musyrik, apa pun jenis kemusyrikannya. Sama halnya dengan pendapat al-Thâbarî, mengutip pemahaman terhadap ayat itu dengan mengatakan: "kamu tidak boleh menikahkan (perempuan Muslim) dengan laki-laki Yahudi atau Kristen dan musyrik yang tidak seagama denganmu". ${ }^{24}$

Dalam hal ini, Quraish Shihab menyatakan bahwa larangan perkawinan perempuan Muslim dengan laki-laki Ahl al-Kitâb diisyaratkan oleh al-Qur`an. Isyarat ini dipahami dari redaksi dalam surah al-Mâidah ayat 5 yang hanya berbicara tentang kebolehan perkawinan laki-laki Muslim dengan perempuan Ahl al-Kitâb, dan sedikit pun tidak menyinggung sebaliknya. ${ }^{25}$ Sehingga, seandainya pernikahan semacam itu dibolehkan, maka pasti ayat tersebut akan menegaskannya.

Rasyid Ridlâ memiliki pendapat yang berbeda. Menurutnya, perkawinan semacam ini bukan karena isyarat larangan seperti

23 Ibn Hazm, al-Muhallâ bi al-Asrâr, juz IX (Beirut: Dâr al-Kutûb al-Ilmiyâh, 1988), hlm. 125 .

${ }^{24}$ Ibn Jarîr al-Thabârî, Jâmi' al-Bayân fí Ta'wîl al-Qur'ân, juz II (Beirut: Dâr al-Kutûb alIlmiyâh, t.t.), hlm. 223.

25 M. Quraish Shihab, Wawasan al-Quran (Bandung: Mizan, 1996), hlm. 197. 
Tajul Arifin

pendapat di atas, tetapi tidak ada penjelasan (maskut 'anhu). ${ }^{26}$ Ada pun yang dijadikan larangan adalah karena tidak adanya kebebasannya dalam rumah tangganya ini, bukan karena hukum asalnya memang dilarang atau isyarat ayat al-Qur`an. Karena hukum asal dalam bidang mu'âmalah, termasuk perkawinan adalah mubah (boleh) selama tidak adanya nash yang melarangnya. ${ }^{27}$

Ustadz Jadid Rifuddin, salah seorang anggota Hidayatullah Solo, memberikan alasan bahwa pernikahan seperti ini dilarang, karena dikhawatirkan perempuan Muslim akan terpengaruh atau berada di bawah kekuasaan yang berlainan agama dengannya. Allah menjelaskan dalam firmannya "mereka mengajak ke neraka", yakni mengajak kepada kekufuran yang akan menjadi sebab masuk ke neraka. Hal ini disebabkan karena seorang laki-laki memiliki kekuasaan dan wewenang atas isterinya. Dengan demikian perempuan tidak memiliki kebebasan dalam rumah tangganya, termasuk kebebasan beragama dan mendidik anak-anaknya. Oleh karena itu, pernikahan antara perempuan Muslim dengan laki-laki non Muslim akan membahayakan agamanya.

Berbeda dengan pemahaman penulis, Amir Syarifudin mengatakan, jika alasan larangan perkawinan perempuan Muslim dengan laki-laki Ahl al-Kitâb dikarenakan perempuan tidak memiliki kebebasan dalam rumah tangganya, karena dalam posisi dipimpin dan harus taat kepada suami, maka bagaimana jika kedudukan perempuan dalam rumah tangga setara atau sederajat dengan suami. ${ }^{28}$ Ini dapat dijumpai dalam beberapa masyrakat, lebih-lebih lagi bagaimana jika dalam rumah tangga justru isteri yang lebih dominan pengaruhnya.

Dengan menggunakan prinsip interpretasi evolusioner, An$\mathrm{Na}^{\prime}$ im cenderung membolehkan perkawinan antara perempuan Muslim dengan laki-laki non Muslim. ${ }^{29}$ Menurut An-Na'im, perkawinan seperti ini dilarang didasarkan pada kombinasi operasi

${ }^{26}$ Rasyîd Ridlâ, Tafsîr al-Qur'ân al-Karîm al-Syahîr bi Tafsîr al-Manâr, juz II (Beirut: Dâr al-Fikr, t.t.), hlm. 351 .

27 Ibid., hlm. 193.

28 Amir Syarifuddin, Pembaharuan Pemikiran dalam Hukum Islam (Padang: Angkasa Raya, 1993), hlm. 83.

29 Abdullahi Ahmed an-Na'im, Dekonstruksi Syari'ah (Yogyakarta: LKiS, 1997), hlm. 345-346. 
perwalian laki-laki, dalam kasus ini suami terhadap isterinya. Karena suami non Muslim tidak dapat menjadi wali isteri Muslimnya, maka hukum Islam melarangnya. Jika perwalian suami terhadap isterinya ini dihapus, maka tidak akan ada lagi pembenaran terhadap larangan perkawinan perempuan Muslim dengan laki-laki non Muslim.

Terhadap asumsi bahwa jika perkawinan tersebut diijinkan, maka suami non Muslim akan memengaruhi isteri Muslimnya keluar dari Islam. An-Na'im mengatakan bahwa asumsi ini pun dapat dihapus dengan prinsip evolusi di atas. Alasan larangan ini, tentu saja bagian dari fenomena sosiologi yang lebih luas, yaitu kelemahan kepercayaan diri dalam integritas perempuan dan keputusannya yang baik.

Dalam hal ini penulis cenderung setuju dengan pendapat Rasyîd Ridhâ, tetapi apabila keadaan terbalik, di mana perempuan mempunyai kedudukan yang lebih dominan dalam keluarga daripada laki-laki, maka perkawinannya dengan laki-laki yang beragama lain diperbolehkan, meskipun dalam kasus yang terbatas.

Berkaitan dengan perkawinan laki-laki Muslim dengan perempuan musyrik Allah swt menetapkan laki-laki Muslim agar jangan menikahi perempuan musyrik hingga mereka beriman. Seperti dalam al-Qur`an yang menegaskan dalam surat al-Baqarah (2): 221, "dan janganlah kamu menikahi perempuan-perempuan musyrik sebelum mereka beriman". Selain itu dalam hadits yang diriwayatkan Bukhâri dan Ibn Umar, Rasulullah bersabda: "Allah mengharamkan kaum Muslim menikahi perempuan musyrik dan saya tidak melihat sesuatu bentuk syirik yang lebih besar daripada perempuan yang menyatakan bahwa Tuhannya Isa, sedangakan Ia adalah hamba Allah".

Perempuan musyrik adalah perempuan penyembah berhala dan patung-patung dan berkeyakinan bahwa berhala-berhala itu dapat jadi mediator untuk mendekatkan seseorang kepada Allah. Selain itu termasuk juga di dalamnya adalah perempuan-perempuan yang percaya adanya banyak Tuhan, percaya ada Tuhan selain Allah atau mereka yang sama sekali tidak percaya adanya Tuhan serta tidak meyakini adanya kitab-kitab Allah dan akhirat. ${ }^{30}$

Menurut Wahbah Zuhaylî, pengertian musyrik menunjuk pada golongan yang tidak menganut agama samawi dan tidak

30 Basyir, Hukum Perkawinan, hlm. 8. 
Tajul Arifin

berkitab samawi. Mereka adalah penyembah berhala, bintang, api atau pun binatang. ${ }^{31}$ Al-Shabuni memberikan cakupan yang lebih luas, yaitu meliputi kaum musyrik Arab, Majusi, Yahudi, Kristen, dan orang-orang murtad dari Islam. ${ }^{32}$ Namun pendapat terakhir ini tidak didukung mayoritas ulamâ', karena Majusi, Kristen, dan Yahudi termasuk kategori Ahl al-Kitâb.

Ustadz Fitrah Taufan dari Pondok Pesantren al-Kahfi Surakarta menambahkan bahwa larangan ini dimaksudkan agar keselamatan keyakinan agama suami dan anak-anaknya dapat terjamin, demikian pula keserasian dan keharmonisaan hidup rumah tangga benar-benar dapat dicapai sesuai dengan tuntutan Islam.

Terakhir, berkenaan dengan perkawinan laki-laki Muslim dengan perempuan Ahl al-Kitâb, ${ }^{33}$ respon para ulamâ' berbeda-beda. Pertama, mereka yang berpendapat bahwa menikahi perempuan Ahl al-Kitâb halal hukumnya. Termasuk dalam golongan ini adalah jumhûr ulamâ', termasuk beberapa ulamâ' fundamentalis di Solo. Ustadz Jadid Arifuddin dengan tegas menyatakan apa pun yang telah tercantum dalam Al-Qur'an merupakan final dari setiap keputusan dalam Islam, apalagi ketika ayat-ayat tersebut bukan merupakan metafora, dan dapat difahami secara langsung. Beliau menambahkan mengenai hal ini, landasannya berdasarkan surat al-Mầidah (5): 5 .

Pendapat ini senada dengan al-Thabârî bahwa pernikahan antara laki-laki Muslim dengan perempuan Ahl al-Kitâb yang merdeka dan menjaga kehormatannya adalah halal, baik kitâbiyyah dzimmiyah maupun harbiyyah. ${ }^{34}$ Menurutnya, keharaman laki-laki Muslim mengawini perempuan non Muslim dalam al-Baqarah (2): 221, telah di-nasakh oleh ayat 5 surat al-Mâ idah yang memberikan pengecualian terhadap perempuan dari golongan Ahl al-Kitâb.

31 al-Zuhaylî, al-Fiqh, hlm. 151.

32 Muhammad Alî Al-Shabûnî, Tafsîr Ayât al-Ahkkâm (Mekkah: Dâr al-Qur'ân, t.t.), hlm. 289

33 Quraish Shihab menegaskan bahwa Ahl al-Kitâb adalah semua penganut agama Yahudi dan Nashrani. Dasarnya adalah penggunaan al-Qur'an terhadap istilah tersebut yang hanya terbatas pada kedua golongan itu. Lihat Shihab, Wawasan alQuran, hlm. 370

34 Al-Thabârî, Jâmi' al-Bayân, hlm. 448. 
Al-Qurtubi juga membenarkan kebolehan pernikahan laki-laki Muslim mengawini perempuan Ahl al-Kitâb yang muhshan. ${ }^{35} \mathrm{Al}$ muhshan adalah perempuan yang menjaga kehormatannya dari melakukan zina. Sedangkan menurut Ali al-Sayis, al-muhshan berarti al-harầir, yakni perempuan merdeka bukan hamba sahaya, dan ada juga yang mengartikan al-afifah, yaitu perempuan yang memelihara kehormatan dirinya. ${ }^{36}$

Para imam madzhab yang empat dalam prinsipnya memiliki pendapat yang sama, yaitu bahwa perempuan Ahl al-Kitâb boleh dinikahi oleh laki-laki Muslim. ${ }^{37}$ Hal ini pernah dipraktikkan oleh sahabat nabi seperti Utsmân, Thalhah, Ibn Abbâs, dan para tâbi'în, seperti Sâ'id ibn al-Musayyab, al-Hasan, dan lain-lain. Alasan dari para imam tersebut adalah meskipun mereka para perempuan Ahl alKitâb berkeyakinan bahwa Isa adalah Tuhan atau meyakini Trinitas, dan itu merupakan syirik yang nyata, tetapi karena mereka memiliki kitab samawi, mereka halal dinikahi sebagai takhshîsh. ${ }^{38}$ Maka dari itu, ketika Ibnu Taymiyah menjawab persoalah pernikahan dengan perempuan Nasrani dan Yahudi, beliau menjawab bahwa ini diperbolehkan karena ada landasan dalam surat al-Mầidah ayat 5 tersebut. Selain itu, jumhûr ulamâ' dan imam madzhab memperbolehkan ini. ${ }^{39}$ Ahl al-Kitâb tidak termasuk kaum musyrik, ayat dalam surat al-Baqarah bersifat umum, sedangkan ayat dalam surat al-Mầidah bersifat khusus.

Golongan kedua, ada ulamâ` yang mengharamkan pernikahan semacam ini. Ustadz Fitrah Taufan, misalnya, beralasan bahwa Ahl alKitâb sama dengan musyrik, yaitu karena Ahl al-Kitâb mempertuhankan orang-orang alim dan rahib-rahib mereka serta Isa al-Masih (QS. al-Tawbah (9): 30-31 dan al-Mầidah (5): 72-73). Menurut beliau, dalam surat al-Mâidah ayat 5 tersebut yang

35 Al-Qurthubi, al-Jâmi li al-Ahkâm al-Qur'an (Kairo: Maktabah Dâr al-Kitâb, 1967), VI: 79.

36 Alî al-Sayîs, Tafsîr Ayât al-Ahkâm, juz II (Mesir: Ma'tabah Muhammâd 'Alî Syâbîh wa aulâduh, 1953), hlm. 168.

37 Abdurrahman I Doi, Perkawinan dalam Syari'at Islam (Jakarta: Rineka Cipta, 1992), hlm. 32.

38 Al-Jazîrî, Al-Figh 'ala Mazâhib al-Arba'ah, juz IV (Beirut: Dâr al-Fikr, 1996), hlm. 6070 .

39 Ibn Taymîyâh, Majmû' Fatawâ, juz XXXII (Mekkah: al-Mamlakâh al-Arabîyâh asSaudîyâh, 1398), hlm. 178-180. 
Tajul Arifin

menjelaskan halalnya laki-laki Muslim menikahi perempuan Ahl alKitâb yang menjaga kehormatannya diartikan apabila mereka telah memeluk Islam. Sehingga jika mereka tetap dalam agama mereka, maka tidak termasuk perempuan terhormat (muhshanât). mereka juga mengatakan bahwa ayat ini telah dihapus oleh surat al-Baqarah ayat 221, sehingga tidak berlaku lagi.

Kalangan sahabat terkemuka dari golongan ini adalah Ibn Umar. Ketika ditanya tentang mengawini perempuan Ahl al-Kitâb, Ibn Umar menjawab: "sesungguhnya Allah mengharamkan perempuanperempuan musyrik bagi laki-laki Muslim. Aku tidak tahu syirik manakah yang lebih besar daripada seorang perempuan yang berkata bahwa Tuhannya adalah Isa, sedangkan Isa adalah seorang di antara hamba Allah".40 Pendapat ini tidak didukung oleh mayoritas sahabat nabi dan ulamâ', ${ }^{41}$ di samping Ahl al-Kitâb tidak sama dengan musyrik, juga karena surat al-Mầidah yang paling akhir turunnya, sehingga tidak dapat dikatakan bahwa ayat ini dibatalkan oleh surah al-Baqarah yang turun lebih dahulu.

Mengomentari pendapat Ibn Umar, Quraish Shihab dapat memahaminya dengan memerhatikan bahwa Ibn Umar dikenal sangat hati-hati serta amat gandrung meniru nabi dalam sikap dan tindakannya. Kehati-hatian dan keganderungan itulah yang menjadikan Ibn Umar begitu ketat dengan pendapat di atas, keketatan yang tidak sejalan dengan kemudahan yang dianugerahkan al-Qur’an. ${ }^{42}$

Sedangkan penulis lebih setuju dengan pendapat Ibrahim Hosen. Menurutnya bahwa di antara golongan yang memandang halal menikahi perempuan Ahl al-Kitâb, ada yang berpendapat bahwa yang dimaksud dengan perempuan Ahl al-Kitâb adalah yang telah membayar jizyah, atas dasar bahwa Ahl al-Kitâb yang tidak membayar jizyah tetap berlaku padanya hukum perang menurut QS. al-Tawbah (9): 29.

Artinya: Perangilah orang-orang yang tidak beriman kepada Allah dan tidak (pula) kepada hari Kemudian, dan mereka tidak mengharamkan apa yang diharamkan oleh Allah dan RasulNya dan

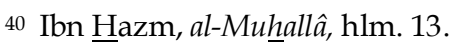

41 Shihab, Wawasan al-Qur'an, hlm. 196.

42 Ibid., hlm. 370. 
tidak beragama dengan agama yang benar (agama Allah), (yaitu orang-orang) yang diberikan al-Kitab kepada mereka, sampai mereka membayar jizyah dengan patuh sedang mereka dalam keadaan tunduk.

Ayat ini menunjukkan bahwa perempuan Ahl al-Kitâb yang tidak membayar jizyah tidak halal dinikahi oleh laki-laki Muslim, karena terhadap mereka tetap berlaku hukum perang. ${ }^{43}$

Menurut qazl mu'tamad dalam madzhab Syâfi'î, perempuan Ahl al-Kitâb yang halal dinikahi oleh laki-laki Muslim ialah perempuan yang menganut agama Nasrani atau Yahudi sebagai agama keturunan dari orang-orang (nenek moyang mereka) yang menganut agama tersebut semenjak masa sebelum Nabi Muhammad diutus menjadi Rasul. Tegasnya, orang yang baru menganut agama Yahudi dan Nasrani setelah al-Qur`an diturunkan, maka mereka itu tidaklah dianggap Ahl al-Kitâb. Jalan pikiran madzhab Syâfi'î ini mengakui bahwa Ahl al-Kitâb itu bukan karena agamanya, melainkan karena menghormati asal keturunannya.

Dihalalkannya laki-laki Muslim menikah dengan perempuan Ahl al-Kitâb adalah karena suami memiliki tanggung jawab kepemimpinan terhadap isteri, serta memiliki wewenang dan fungsi pengarahan terhadap keluarga dan anak-anaknya. Dengan kelakuan dan komunikasi yang baik dari suami akan membawa misi kasih sayang dan kesan yang harmonis, dengan demikian akan membawa kesan bahwa Islam adalah agama lurus, mengajak kepada yang haq, berbuat adil baik terhadap sesama Muslim maupun non Muslim. ${ }^{44}$

Meskipun mayoritas ulamâ' memperbolehkan pernikahan laki-laki Muslim dengan perempuan Ahl al-Kitâb, tetapi tetap harus dibarengi dengan syarat-syarat yang harus dipenuhi oleh calon suami, yakni ia harus mampu melaksanakan agamanya dengan baik, menjadi pemimpin isteri dan rumah tangganya, termasuk pendidikan anak-anaknya. Yûsuf Qardlawi mengemukakan hal-hal yang harus diperhatikan, yaitu:

1. Perempuan Ahl al-Kitâb itu benar-benar berpegang pada ajaran samawi.

43 Ibrahim Hosen, Fiqih Perbandingan Masalah Pernikahan (Jakarta: Pustaka Firdaus, 2003), hlm. 290-291.

44 Ridlâ, Tafsîr al-Qur'ân, hlm. 351. 
Tajul Arifin

2. Perempuan Ahl al-Kitâb yang muhshanah.

3. Ia bukan Ahl al-Kitâb yang kaumnya berada pada status permusuhan dengan kaum Muslim.

4. Di balik pernikahan itu tidak akan terjadi fitnah, yaitu mafsadah, semakin besar kemudaratannya, semakin besar tingkat keharamannya. ${ }^{45}$

5. Bagi perempuan Ahl al-Kitâb yang bersuami laki-laki Muslim berlaku hukum Islam dalam rumah tangganya seperti halnya bagi perempuan Muslim, misalnya mandi junub, haid, dan lainlain. 46

Dengan memberikan syarat-syarat seperti di atas, dapat dipahami, bahwa memang seharusnya orang-orang yang akan melangsungkan pernikahan beda agama harus berfikir ulang akan kelangsungan pernikahannya. Maka dari itu, meskipun mayoritas ulamâ' membolehkan, namun kebanyakan dari mereka, menurut Ibn Qudamah, berpendapat sebaiknya tidak menikahi perempuan Ahl alKitâb, dan perempuan Muslim lebih baik dari mereka.

Lalu bagaimana seharusnya, hukum perkawinan yang berlaku bagi tiap-tiap agama satu sama lain ada perbedaan, akan tetapi tidak saling bertentangan. Ada pun di Indonesia telah ada hukum perkawinan yang secara otentik diatur di dalam UU. No. 1 Th. 1974, yang mana dalam undang-undang ini belum secara detail mengatur tentang perkawinan beda agama, pengaturan yang ada hanya perkawinan campuran. Padahal, menurut Ustadz Medi, Islam merupakan Rahmatan li al-âlamîn, maka sudah selayaknya semua hukum produk al-Qur'an dijadikan pedoman untuk undang-undang yang berlaku di Indonesia. Begitu pula dengan Ustadz Jadid yang berpendapat bahwa, Indonesia merupakan Negara Muslim terbesar di dunia, "Arab Saudi saja memakai hukum Islam, kenapa kita yang lebih besar tidak juga menggunakannya".

\section{Penutup}

Perkawinan beda agama tidak semata-mata dipahami secara normatif-teologis belaka, karena masalah ini terkait erat dengan

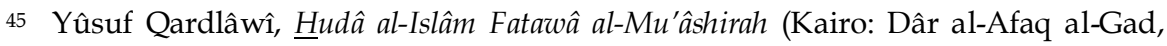
1978), hlm. 407.

46 Peunoh Daly, Hukum Perkawinan Islam (Jakarta: Bulan Bintang, 1988), hlm. 80. 
faktor-faktor sosiokultural. Perkawinan beda agama di Indonesia (inter-faith marriage) di Indonesia secara objektif-sosiologis adalah sesuatu yang wajar, mengingat penduduk Indonesia sangat pluralistik, baik dari segi suku, etnis, budaya, bahasa maupun agama, sedangkan pergaulan dan interaksi antar berbagai komunitas sangat intens, bebas dan terbuka. Sehingga, sangat besar kemungkinan akan terjadinya ketertarikan dan saling jatuh cinta antara dua insan yang berbeda tersebut.

Begitu pun dalam Undang-undang Perkawinan No. 1 Tahun 1974, secara eksplisit mengindikasikan bahwa perkawinan beda agama tidak dikehendaki di Indonesia. Ini terlihat dalam beberapa pasal seperti pasal 2 ayat (1) dan pasal 8 huruf (f). Begitu pun dalam KHI buku I tentang perkawinan yaitu pasal 40, 44, dan 60. Ini menandakan kurangnya sensitivitas para pembuat kebijakan pada faktor sosiologis.

Berdasarkan penelitian yang penulis lakukan, ternyata perkawinan beda agama di Solo merupakan fenomena yang benarbenar nyata, mengingat kultur pluralistik kota ini, banyaknya budaya, etnis dan agama menjadi faktor dominan penyebab banyaknya terjadi penikahan beda agama. Respon yang diberikan beberapa ulamâ" di solo terhadap persoalan ini, hampir semua jawaban yang penulis dapatkan sangatlah normatif. Karena bagi mereka persoalan produk hukum agama haruslah difahami secara tekstual saja, karena keputusan Tuhan yang ada dalam al-Qur`an merupakan keputusan final dalam persoalan apa pun kecuali jika belum secara jelas tertera.

\section{Daftar Pustaka:}

'Alim. Yûsuf Hâmid, al-Maqâshid al-'âmmah li al-Syarî'ah al-Islâmiyyah. USA: Internasional Graphics Printing Service, 1991

Ahmad, Amrullah (ed.). Dimensi Hukum Islam dalam Sistem Hukum Nasional. Jakarta: Gema Insani Press, 1996

al-Jamal, Ibrahim Muhammad. Fiqih Wanita Islam. Jakarta: Pustaka Panjimas, 1991

An-Na'im, Abdullahi Ahmed. Dekonstruksi Syari'ah. Yogyakarta: LKiS, 1997

Azhary, Tahir. Bunga Rampai Hukum Islam. Jakarta: Ind-Hill-Co, 1992

Basyir, Ahmad Azhar. Hukum Perkawinan Islam. Yogyakarta: UII Press, 2000 
Tajul Arifin

Brenner, Suzanne April, The Domestication of Desire: Women, Wealth, and Modernity in Java, Princeton, N.J.: Princeton University Press, 1998

Daly, Peunoh. Hukum Perkawinan Islam. Jakarta: Bulan Bintang, 1988

El Fadl, Khaled M. Abou. Atas nama Tuhan; dari Fikih Otoriter ke Fikih Otoritatif, terj. R. Cecep Lukman Yasin. Jakarta: Serambi Ilmu Semesta, 2004

Eoh, Octavianus. Masalah Perkawinan antara Dua Orang yang Berbeda Agama setelah Berlakunya UU No. 1 Tahun 1974 tentang Perkawinan. Tesis Program Pascasarjana UGM Yogyakarta, 1990

Florida, Nancy K. Writing the Past, Inscribing the Future: History as Prophesy in Colonial Java. Duke University Press, 1995

Florida, Nancy K. Javanese Literature in Surakarta Manuscripts / Vol. 1 Introduction and Manuscripts of the Karaton Surakarta. Ithaca: Cornell University, Southeast Asia Program (SEAP), 1993

Fuaddudin. Pengasuhan Anak dalam Keluarga Islam. Jakarta: Lembaga Kajian Agama dan Gender, 1999

Hakim, Rahmat, Hukum Perkawinan Islam, Bandung: Pustaka Setia, 2000

Hamidah, Tutik. Peraturan Perkawinan Antar Agama di Indonesia (Perspektif Muslim). Tesis Program Pascasarjana UIN Sunan Kalijaga, Yogyakarta, 2000

Haroen, Nasrun. Ushul Fikih I. Bandung: Logos, 1997

Hawari, Dadang. Al-Quran Ilmu Kedokteran Jiwa dan Kesehatan Jiwa. Yoyakarta: Dana Bakti Prima Yasa, 1995

Hazairin, Tinjauan Mengenai Undang-undang No. 1 Tahun 1974. Jakarta: Tintamas, 1986

Hazm, Ibn. al-Muhallâ bi al-Asrâr. Beirut: Dâr al-Kutub al-Ilmiyah, 1988

Hosen, Ibrahim. Fiqih Perbandingan Masalah Pernikahan. Jakarta: Pustaka Firdaus, 2003

I Doi, Abdurrahman. Perkawinan dalam Syari'at Islam. Jakarta: Rineka Cipta, 1992

Ibn Katsir, Abû al-Fida Ismâ'il. Tafsîr al-Qur'ân al-Azhîm,. T.tp: Dâr Mishr li Thabâ'ah, t.t.

Ichtijanto. Perkawinan Campuran dalam Negeri RI: Suatu Studi ke Arah Hukum yang Dicita-Citakan. Jakarta: Hukum dan Pembangunan, 1993 
Jawhar, Ahmad al-Mursi Husayn. Maqâshid al-Syarî́ah. Jakarta: Amzah, 2009

Jazirî al-. al-Fiqh 'alâ Madzâhib al-Arba'ah. Beirut: Dâr al-Fikr, 1996

Khallâf, Abd al-Wahab, Ushûl al Figh. Kairo: Dâr al Qalam, 1978

Laporan Jurnalistik Kompas. Ekspedisi Bengawan Solo. Jakarta: Kompas, 2009

Larson, George D. Prelude to revolution: Palaces and politics in Surakarta, 1912-1942. Dordrecht, Holland and Providence, R.I., U.S.A.: Foris Publications, 1987

Mahfud MD, (ed.). Peradilan Agama dan Kompilasi Hukum Islam dalam Tata Hukum Indonesia. Yogyakarta: UII Press, 1993

Majid, Nurcholis, et al. Fiqih Lintas Agama; Membangun Masyarakat Inklusif Pluralis. Jakarta: Yayasan Wakaf Paramadina, 2003

Martin, Richard C. (ed.), Pendekatan dalam kajian Islam dalam studi Agama, terj. Zakiyuddin Bhaidhawi. Surakarta: Muhammadiyah University Press, 2002

Mawardi, Abî Hasan 'Ali al-, al-Nukat wa al-'Uyût Tafsîr al-Mawardi. Bairut: Dar al-Kutub al-'Alamiyyah, t.t

Miksic, John (general ed.). Karaton Surakarta. A look into the court of Surakarta Hadiningrat, central Java (First published: 'By the will of His Serene Highness Paku Buwono XII'. Surakarta: Yayasan Pawiyatan Kabudayan Karaton Surakarta, 2004

Misrawi, Zuhairi. Al-Qur'an Kitab Toleransi; Inklusivisme, Pluralisme dan Multikulturalisme. Jakarta: Fitrah, 2007

Moleong, Lexy J. Metodologi Penelitian Kualitatif. Bandung: PT. Remaja Rosdakarya, 2005.

Mudzhar, M. Atho. Fatwa-Fatwa Majelis Ulama Indonesia. Jakarta: INIS, 1993.

Nadawi, Alî Ahmad al-. al-Qawấ'id al-Fiqhiyyah. Damaskus: Dâr alQalam, 1991

Nasution, Khoruddin. Islam Tentang Relasi Suami dan Istri (Hukum Perkawinan 1) Dilengkapi Perbandingan UU Negara Muslim. Yogyakarta: Academia dan Tazzafa, 2004.

Qardlawî, Yûsuf. Hûûâ al-Islâm Fatawâ al-Mu'âshirah. Kairo: Dâr alAfaq al-Gad, 1978.

Ramulyo, Moh. Idris. Hukum Perkawinan Islam (Suatu Analisis Dari Undang-Undang No. 1 Tahun 1974 dan Kompilasi Hukum Islam. Jakarta: PT Bumi Aksara, 1996 
Tajul Arifin

Ridlâ, Rasyîd. Tafsîr al-Qur'an al-Karîm al-Sahîr bi Tafsîr al-Manâr II. Beirut: Dâr al-Fikr, t.t.

Rusli dan R. Tama, Perkawinan Antar Agama dan Permasalahannya. Bandung: Pionir Jaya, 1986

Sâbiq, Sayyid. Fiqh as-Sunnah. Beirut: Dâr al-Fikr, 1983

Shabuni al-, Tafsîr Ayât al-Ahkk̂̂m. Mekkah: Dâr al-Qur`an, t.t

Salam, Zarkasji Abdul. "Perkawinan Antar Orang Yang Berbeda Agama (Muslim Dengan Non Muslim)." Jurnal Penelitian Agama, Th. IV, No. 9 (Januari-April 1995)

Shihab, M. Quraish. Menabur Pesan Illahi, Al-Quran dan Dinamika kehidupan Masyarakat. Jakarta: Lentera Hati, 2006

Shihab, M. Quraish. Wawasan al-Qur'an Tafsir Maudu'i atas Pelbagai Persoaan Umat. Bandung: Mizan, 1996

Shihab, M. Quraish. Tafsir al-Misbah: Pesan, Kesan dan Keserasian alQur'an, Vol. 10. Jakarta: Lentera Hari, 2002

Sidharta, P. H. Undang-Undang Perkawinan ditinjau dari Segi Hukum Antar Tata Hukum Perdata Pada Dewasa Ini. Jakarta: Hukum dan Pembangunan, 1992.

Siegel, James T. Solo in the New Order: Language and hierarchy in an Indonesian City. Princeton, N.J.: Princeton University Press, 1986.

Subrata, Sumardi. Metodologi Penelitian. Jakarta: PT. Raja Grafindo Persada, 1983.

Surahman, Winarno. Metodologi Penelitian, Jakarta: Rajawali, 1989.

Susanto, Edi. "Pendidikan Agama Berbasis Multikultural: Upaya Strategis Menghindari Radikalisme". KARSA: Jurnal Studi Keislaman, Vol. IX No. I (April 2006).

Syarifuddin, Amir. Pembaharuan Pemikiran dalam Hukum Islam. Padang: Angkasa Raya, 1993

Team Media. Amandemen UU Peradilan Agama (UU RI No. 3 Tahun 2006), Undang-undang Peradilan Agama (Nomor 7 Tahun 1989) dan Kompilasi Hukum Islam. t.t: Media Centre, t.t

Thabari, Ibn Jarîr al-. Jami' al-Bayân fî Ta'wîl al-Qur'ân, II. Beirut: Dâr al-Kutub al-Ilmiyah, t.t

Thaha, Abdul Azis. Islam dan Negara dalam Politik Orde Baru. Jakarta: Gema Insani Press, 1996.

Tim Ditbinbapera. Berbagai Pandangan Terhadap Kompilasi Hukum Islam. Jakarta: Yayasan al-Hikmah, 1993 
Wahyudi, Yudian. Ushul Fikih versus Hermeneutika; Membaca Islam dari Kanada dan Amerika. Yogyakarta: Nawesea Press, 2006.

Zuhayli, Wahbah. al-Figh al-Islâm wa Adillatuh, VII. Beirut: Dâr al-Fikr, 1989.

Zuhayli, Wahbah. Ushûl al-Figh al-Islâmi, Jilid. II. Damaskus: Dâr alFikr, 1986.

Zulkarnaen. Perkawinan Antar Agama di Indonesia Suatu Studi Yuridis. Jakarta: Ilmu dan Budaya, 1990. 